\title{
Air Quality During COVID-19: Analysis of Particulate Matter for a Coastal Urban Station Visakhapatnam(India)
}

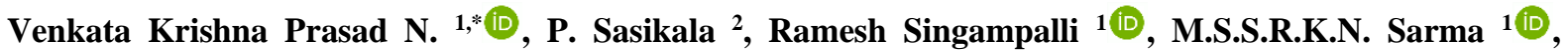 \\ Thomaskutty Mathew ${ }^{1}$ (D), N. Madhavi ${ }^{3}$ \\ 1 Department of Physics, School of Science, GITAM University, Bengaluru, India \\ 2 Department of Mathematics, GSS, GITAM University, Bengaluru, India \\ 3 Department of Statistics, Govt. College (Autonomous), Rajahmundry, India \\ * Correspondence: drnvkprasad@gmail.com;
}

Scopus Author ID 8356816900

Received: 4.09.2020; Revised: 30.09.2020; Accepted: 1.10.2020; Published: 3.10.2020

\begin{abstract}
The last day of the year 2019 (December 31st), a new infection, coronavirus, was reported from Wuhan (China) to WHO. Subsequently, it was named COVID-19 disease and being declared pandemic on the $11^{\text {th }}$ of March 2020. It was one of the ever faced challenges, and 40 to 60 percent of the world population was estimated to be affected by this virus. This led to severe crises in all countries in terms of economic, social, and environment, emphasizing health. To avoid transmission of this virus worldwide, the lockdown was implemented. This lockdown started on $23^{\text {rd }}$ January 2020 in some parts of the world that impacted the environment and air quality of various cities, depending on their socioeconomic conditions. As per the ESA (European Space Agency) and NASA (National Aeronautics and Space Administration), Wuhan experienced a 30\% reduction in air pollution. It is a known fact that air pollution has a major impact on human health; the effect of lockdown in various cities and its impact on air pollution prompt us to review some of the recent results published in a nutshell. This paper presented some of the results related to air pollution before and after the announcement of lockdown in various cities around the globe, including Visakhapatnam (India) a polluted coastal urban station with more emphasis on $\mathrm{PM}_{2.5}$ and $\mathrm{PM}_{10}$ concentrations along with air pollutants like $\mathrm{NO}_{2}, \mathrm{SO}_{2}, \mathrm{NO}, \mathrm{CO}$ and Relative Humidity.
\end{abstract}

Keywords: COVID-19; environmental pollution; $\mathrm{PM}_{2.5}$; $\mathrm{PM}_{10}$; air pollutants.

(C) 2020 by the authors. This article is an open-access article distributed under the terms and conditions of the Creative Commons Attribution (CC BY) license (https://creativecommons.org/licenses/by/4.0/).

\section{Introduction}

An unknown respiratory disease was identified in December 2019 in a wet market (Huanan Seafood) in China, later called COVID-19. It was caused by the SARS-Cov-2 virus, which was new and its infection in humans was the first to be reported. This disease, which originated in China, quickly infected all countries worldwide [1-3]. On March 11th, 2020, the WHO declared the disease as a global pandemic[4]. This was a deadly virus reported the first time in 100 years in December 2019 [5]. As per the data of WHO the number of COVID-19 cases as of August 6th 2020 in India was confirmed (1.91 million), recovered (1.28 million), death $(39,795)$ while the cases for the rest of India are confirmed (18.8 million), recovered(11.3 million) and death(7 lakhs). The current lockdown scenario has shown a huge impact on cities that are urbanized, leading to sudden blockage of transport and shutdown in industries with almost zero traffic. This situation brought a change in the global environment and the environment, depending on local conditions that need to be monitored. Studies related to air 
quality and its impact on human health come into the limelight in this context. Emissions of $\mathrm{CO}, \mathrm{CO}_{2}, \mathrm{SO}_{\mathrm{x}}$, and particulate matter were greater in quantity than previous literature. Cohen et al. reported that roughly 4.2 million premature deaths occur in the world [6]. As per WHO 2018 report, the annual death rate of people because of respiratory diseases due to $\mathrm{PM}_{2.5}$ particle concentration was seventy crores[7]. The total population worldwide living in areas with poor air quality is about $91 \%$ [8]. To avoid the transmission of this virus, a lockdown was implemented. This stopped global activity for a few months based on individual decisions made by country heads. At the same time, this pandemic helped to improve air quality in many cities with decreased pollution. This worldwide closure is of prime interest in analyzing environmental data and may achieve good scientific results if any.

\subsection{World's most polluted capitals during the lockdown.}

As per WHO air quality should not exceed $10 \mathrm{mg} / \mathrm{m}^{3}$ of yearly mean concentration. Meteosim's 2019 document [9] reported Delhi, India's capital, as the most polluted capital with a yearly mean of $113,5 \mathrm{mg} / \mathrm{m}^{3} \mathrm{PM}_{2.5}$ concentration for the year 2018. Daniella and Leonardo, in their excellent review, reported that $27 \%$ capitals of Asian countries tended to decrease $\mathrm{PM}_{2.5}$ concentration except cities: Tokyo (Japan), Kathmandu(Nepal), Jakarta(Indonesia), and Singapore, which show an increasing trend. They reported the highest weekly averages of 183 $\mathrm{mg} / \mathrm{m}^{3}$ and $140 \mathrm{mg} / \mathrm{m}^{3} \mathrm{PM}_{2.5}$ for Dhaka (Bangladesh) and Delhi (India) with 24\% and 40\% reductions during lockdown week. At the same time, seventeen of the analyzed European capitals recorded a decrease of $\mathrm{PM}_{2.5}$ concentration by $23 \%$ on average while Bogota (Colombia) from the American continent exhibit the highest reduction of 57\% $\mathrm{PM}_{2.50 u t}$ of the four analyzed capitals [10].

\subsection{Measurements of air pollution (Outside India).}

Hanaoka and Masui reported reduced $\mathrm{CO}_{2}$ emissions by $25 \%$ in China and by $6 \%$ worldwide [11]. Dutheil et al. made a comparative analysis of annual deaths due to $\mathrm{NO}_{2}$ emissions with deaths due to COVID-19. They reported the advantages due to home isolation[12]. Muhammad et al. compiled information from NASA and ESA and reported that it benefits North America, China, and Europe environmentally temporarily [13]. Mollalo et al. developed a regression model with thirty-five variables from socio-economic to environmental related to the disease in first three months of the outbreak in the USA [14]. Ogen reported that $78 \%$ of 4443 deaths occurred in a single day on $19^{\text {th }}$ March 2020 in Europe are from five highly contaminated areas. It indicates long-term exposure to particulate pollutants acts as a major contributor to the entire world[15]. Bruno et al reported a significant reduction in CO and NO2 levels in Rio de Janeiro (Brazil). They reported a reduction in $\mathrm{PM}_{10}$ and an increase in ozone (attributed to an increase in NMHC/NOx ratios) in all study locations during the first partial lockdown [16]. Matthew D.Adams reported measured hourly air pollution for fine particulate matter, ozone, oxides of nitrogen, and nitrogen dioxide from the air monitoring network of Ontario (Canada) for 2020 and the previous five years. Reports indicated no significant reduction in fine particulate matter with a reduction in ozone concentration at twelve of the thirty-two monitors than previous years. Nitrogen oxide and nitrogen dioxide show the lowest concentration for 22 of 29 monitors. However, they observed no variation in fine particulate matter from historic values [17]. Teresa To et al. studied the temperature effect on COVID-19 for Canada using daily meteorological data with statistical modeling along with 77,700 plus 
cases between January to May 2020 and indicated no dependence of the virus on ambient temperature [18]. Yichen Wang et al. reported the impact of traffic reduction and reduced industrial emissions on air quality during the lockdown in China. They studied AQI and concentrations of six pollutants $\left(\mathrm{O}_{3}, \mathrm{CO}, \mathrm{NO}_{2}, \mathrm{SO}_{2}, \mathrm{PM}_{2.5}\right.$, and $\left.\mathrm{PM}_{10}\right)$ during the COVID-19 control period in northern China. They observed improvement in air quality because of reduced emissions from transport and secondary industrial sectors. They also reported a reduction in $\mathrm{CO}, \mathrm{NO}_{2}, \mathrm{SO}_{2}$, and $\mathrm{PM}_{2.5}$ concentrations with an increase in $\mathrm{O}_{3}$. But these reductions could not eliminate air pollution [19]. Maria A. Zoran et al. investigated the correlation between the extent of increased diffusion, the capacity of causing the virus, and surface air pollution in Milan(Italy). Daily average concentrations of $\mathrm{PM}_{2.5}, \mathrm{PM}_{10}$, Relative Humidity, Temperature, PBL Height, Wind Speed, and Atmospheric Pressure between January-April 2020 were collected and analyzed. They reported an increase in confirmed COVID-19 cases due to a high level of urban air pollution, instead of indoor transmission or direct human-to-human contact [20]. Pengfei Wang et al. reported severe air pollution in North China inspite of reduced activity due to COVID-19[21]. They analyzed that the benefit of reduced emission was masked by adverse meteorology, and severe air pollution could not be avoided. Jianbang Xiang et al., for the first time, reported the impact of COVID-19 virus on the roadside ultrafine particles[22]. They reported the impact of the virus on air pollution-related to traffic for a US city by collecting data five weeks before and ten weeks after lockdown, which showed a significant decrease in ultrafine particles by $4 \%$ to $29 \%, \mathrm{PM}_{2.5}(33 \%), \mathrm{NO}(33 \%), \mathrm{NO}_{2}(29 \%), \mathrm{NO}_{\mathrm{x}}(30 \%)$, and $\mathrm{CO}(17 \%)$. Akanksha Chauhan and Ramesh P.Singh in their short communication reported a decline in $\mathrm{PM}_{2.5}$ concentration in major cities around the world that include Mumbai \& Delhi (India), Shanghai \& Beijing (China), Rome (Italy), Zaragoza (Spain), Dubai (UAE), New York and Los Angeles (USA) during COVID-19 lockdown[23]. Huang Zheng et al. investigated the change in source contributions, chemical composition, and local transport of $\mathrm{PM}_{2.5}$ particles during the lockdown and compared with 2019 for Wuhan's city. They indicated a decrease of $\mathrm{PM}_{2.5}$ concentration with $92 \%$ emission reduction [24]. Jose M.Baldasanoinvestigated air quality by $\mathrm{NO}_{2}$ during the lockdown in two big cities, Madrid and Barcelona in Spain, and reported reductions of $\mathrm{NO}_{2}$ concentration by $62 \%$ and $50 \%$ [25]. The dependence of PM concentration on Relative Humidity was reported in a detailed manner [26].

\subsection{Measurements of air pollution (within India).}

India imposed a nationwide lockdown in par with other countries (period may change from country to country) from March 24th to May 3rd 2020. During this period, restrictions undoubtedly reduced pollution in all cities throughout the country, which is not an alternative in controlling air pollution. Shubham Sharma et al.[27] analyzed different pollutants between March 16th to April 14th of 2017 to 2020 for 22 cities region-wise that include Bhopal and Dewas (Central India), Patna, Jorapokhar, Brajrajnagar, Kolkata and Gaya (East India), Amritsar, Faridabad, Agra, Jodhpur, Delhi, Varanasi and Kanpur (North India), Chennai, Thiruvanthapuram, Bengaluru and Amravati (South India), and Mumbai, Ahmadabad, Pune and Nagpur (West India). Hourly concentrations of $\mathrm{NO}_{2}, \mathrm{O}_{3}, \mathrm{SO}_{2}, \mathrm{CO}, \mathrm{NO}_{x}, \mathrm{PM}_{10}$, and $\mathrm{PM}_{2.5}$ along with temperature, relative humidity, wind direction, and wind speed obtained from the official Pollution Control Board website were analyzed. They reported a decrease of PM10 (31\%), $\mathrm{PM}_{2.5}$ (43\%), $\mathrm{CO}(10 \%), \mathrm{NO}_{2}(18 \%)$, while having an increase in ozone by $17 \%$ and a negligible change in $\mathrm{SO}_{2}$ during the lockdown period in comparison with previous years for all cities. AQI is reported to reduce by 44\%, 33\%, 29\%, 15\%, and 32\% in North, South, East, 
Central, and Western India. Prashant Kumar et al. [28] analyzed in-situ measured ambient air quality for Delhi, Hyderabad, Chennai, Mumbai, and Kolkata between 2015 to 2020. They reported a substantial reduction of $\mathrm{PM}_{2.5}$ concentration, from 41\%-53\% (Delhi), 26\%-54\% (Hyderabad), 19\% to 43\% (Chennai), 10\%-39\% (Mumbai) and 24\%-36\% (Kolkata). Cities with high volume in traffic recorded high reductions. Indrajit Chowdari et al. studied the impact of lockdown on air pollutants and aerosol concentration to analyze pre-monsoon cloud-toground and inter-cloud lightning activity about these pollutants for Kolkata. They reported a reduction of more than $40 \%$ in these pollutants due to lockdown, which reduces Kolkata's lightning activity [29]. Susanta Mahato et al. studied the air quality data during lockdown for one of the most polluted cities and capital of India(Delhi). Air quality data of $\mathrm{PM}_{2.5}, \mathrm{PM}_{10}$, $\mathrm{NO}_{2}, \mathrm{SO}_{2}, \mathrm{CO}, \mathrm{NH}_{3}$, and $\mathrm{O}_{3}$ from thirty-four monitoring stations spread over Delhi was analyzed. The results demonstrated remarkable improvement with a 50\% reduction in $\mathrm{PM}_{10}$ and $\mathrm{PM}_{2.5}$ levels compared to the pre-lockdown phase. In comparison, other pollutants show a reduction of $\mathrm{CO}$ by $30.35 \%$ and $\mathrm{NO}_{2}$ by $52.68 \%$. Air quality improved by $40 \%$ to $50 \%$ with four days after the commencement of lockdown. Reduction in NAQI was found to be $49 \%$ (Eastern), 37\% (Western), 31\% (Northern), 43\% (Southern) and 54\% (Central) parts of Delhi [30].

\subsection{Measurements of air pollution (Visakhapatnam).}

Visakhapatnam is one of the fast-growing cities in the state of Andhra Pradesh (India). It is a coastal, urban, and industrial station with continuously increasing population and traffic daily. At present, it has an approximate population of 24 lakhs in 2019, which is increased by 20\% when compared to 2011 (Population Research Centre, Andhra University). As per the statistics of Visakhapatnam City Police 8 lakhs vehicles of all types move in the city every day. Every year nearly 20,000 new vehicles are being added. The city is encountering a huge construction activity daily. Because of these activities and tremendous anthropogenic activities, air pollution is of prime concern due to industry's uncontrolled emissions, destruction of municipal waste, vehicles, etc. There will be a drastic degradation of air quality and variation in environmental parameters that need to be analyzed given their effect on health and to be stabilized by taking proper measures.

Review of CPCB and Comprehensive Environmental Pollution Index (CEPI) by the Ministry of Environment and Forests identified Visakhapatnam as one of the critically polluted stations. Regular measurements of the atmospheric parameters like solar UV-B radiation were started in Visakhapatnam in 1985 as part of the Indian Middle Atmosphere Programme (IMAP). However, emphasis on the measurement of air quality index and its related parameters gained significance only after the initiation of NAMP (National Air Quality Monitoring Program) in 1984.

As per the standards of National Ambient Air Quality set by the Central Pollution Control Board (CPCB), the concentration of RSPM in ambient air (24 hours) for an industrial site is $150 \mu \mathrm{g} / \mathrm{m}^{3}$; for sensitive areas, it is $75 \mu \mathrm{g} / \mathrm{m}^{3}$ and for other sites is $100 \mu \mathrm{g} / \mathrm{m}^{3}$ [31]. The yearly mean values for sensitive, residential, and industrial areas of Visakhapatnam are reported to be $50 \mu \mathrm{g} / \mathrm{m}^{3}, 60 \mu \mathrm{g} / \mathrm{m}^{3}$, and $120 \mu \mathrm{g} / \mathrm{m}^{3}$ and respectively [32]. It is reported that the SPM level in the residential areas of Visakhapatnam is high. In contrast, the $\mathrm{NO}_{2}$ level in the residential areas is moderate [32]. As per the CPCB, the RSPM levels are reported to exceed by a factor of 1.0 - 1.5 at almost all urban locations of Visakhapatnam while average with exceeding a factor of 0.50 to 1 in industrial locations of Visakhapatnam. This situation needs 
to be addressed immediately. It is reported that very few research papers have been published about the monitoring and analysis of PM for Visakhapatnam station to date [33]. Hence, the present study may help us know the status of existing air quality at this industrial station before and after lockdown and instigate some strategic plans for ensuring a better and healthy environment for Visakhapatnam. In this context, an attempt was made to analyze $\mathrm{PM}_{2.5}$ and $\mathrm{PM}_{10}$ in terms of $\mathrm{NO}_{2}, \mathrm{SO}_{2}, \mathrm{NO}, \mathrm{NOx}, \mathrm{CO}, \mathrm{NH}_{3}, \mathrm{RH}$, and temperature before and after lockdown situation, through regression analysis. The idea is to check the dependence of $\mathrm{PM}_{2.5}$ and $\mathrm{PM}_{10}$ concentrations on other variables and use the model to forecast the concentration of particulate matter for this urban station Visakhapatnam. The same exercise will be continued with $\mathrm{NO} 2, \mathrm{SO} 2, \mathrm{NO}, \mathrm{CO}$, and $\mathrm{NH}_{3}$ concentrations as dependent variables while others are independent variables. This will be done by comparing the cost of trace gas monitoring instruments.

\section{Materials and Methods}

\subsection{Data.}

Hourly values of $\mathrm{PM}_{2.5}, \mathrm{PM}_{10}, \mathrm{NO}_{2}, \mathrm{SO}_{2}, \mathrm{NO}, \mathrm{CO}$, and $\mathrm{RH}$ for the period March 1st, 2018- June 30th, 2020 from the Central Pollution Control Board's official website were downloaded[34]. From these values, monthly means and standard deviations were calculated. Since the data was obtained from the Government's Website, it is assumed that no compromise in quality exists.

\subsection{Modelling.}

To assess the dependence of $\mathrm{PM}_{2.5}$ and $\mathrm{PM}_{10}$ on other parameters during the lockdown, data was considered from March 2020 to August 2020. With the Multiple Regression Model's help, considering $\mathrm{PM}_{2.5}$ and $\mathrm{PM}_{10}$ as dependent variables, and $\mathrm{NO}_{2}, \mathrm{SO}_{2}, \mathrm{NO}, \mathrm{CO}$, and $\mathrm{RH}$ as independent variables and relevant feature analysis was done. The summary table is given below.

Table 1 (a). Significance level between $\mathrm{PM}_{2.5}$ and other variables.

\begin{tabular}{|l|l|}
\hline Regression Statistics \\
\hline Multiple R & 0.706778794 \\
\hline R Square & 0.499536264 \\
\hline Adjusted R Square & 0.481872838 \\
\hline Standard Error & 7.50384215 \\
\hline Observations & 177 \\
\hline
\end{tabular}

\begin{tabular}{|l|l|l|l|l|l|}
\hline S.No & & Coefficients & Standard Error & t Stat & P-value \\
\hline 1 & Intercept & 31.97643554 & 10.39897232 & 3.074961118 & 0.00245358 \\
\hline 2 & RH & -0.390854511 & 0.135766692 & -2.878868931 & 0.00450408 \\
\hline 3 & SO2 & -0.070648447 & 0.228999747 & -0.308508843 & 0.758072893 \\
\hline 4 & NO & 0.525266073 & 0.637928482 & 0.823393355 & 0.411437932 \\
\hline 5 & NO2 & 0.779539406 & 0.404465145 & 1.927333951 & 0.055605261 \\
\hline 6 & CO & 8.663185508 & 2.476118684 & 3.498695586 & 0.000596865 \\
\hline
\end{tabular}

The values in Table 1(a) show multiple correlation coefficient $\mathrm{R}=0.706$ indicating a positive relationship between $\mathrm{PM}_{2.5}$ and the independent variables. R-Square's value is about $50 \%$ of the variation in PM2.5 explained by the independent variables, and the independent variables $\mathrm{RH}$ and $\mathrm{CO}$ are significant. 
The summary table for PM 10 and relevant parameters is obtained as follows:

Table 1(b). Significance level between $\mathrm{PM}_{10}$ and other variables.

Regression Statistics

\begin{tabular}{|l|l|}
\hline Multiple R & 0.696961465 \\
\hline R Square & 0.485755284 \\
\hline Adjusted R Square & 0.46760547 \\
\hline Standard Error & 19.39184321 \\
\hline Observations & 177 \\
\hline
\end{tabular}

\begin{tabular}{|l|l|l|l|l|l|}
\hline S.No & & Coefficients & $\begin{array}{l}\text { Standard } \\
\text { Error }\end{array}$ & t Stat & P-value \\
\hline 1 & Intercept & 112.4456242 & 26.87359845 & 4.184241439 & $4.57809 \mathrm{E}-05$ \\
\hline 2 & RH & -1.208976798 & 0.350855782 & -3.445794145 & 0.000717375 \\
\hline 3 & SO2 & -0.462047971 & 0.591793791 & -0.780758397 & 0.436030441 \\
\hline 4 & NO & 0.443916052 & 1.648570007 & 0.269273401 & 0.788045843 \\
\hline 5 & NO2 & 2.161554221 & 1.045241161 & 2.067995695 & 0.040155054 \\
\hline 6 & CO & 10.30387874 & 6.398922622 & 1.610252124 & 0.109198087 \\
\hline
\end{tabular}

The values in Table 1(b) show multiple correlation coefficient $\mathrm{R}=0.697$ indicating a positive relationship between $\mathrm{PM}_{10}$ and the independent variables. R-Square's value is about $49 \%$ of the variation in $\mathrm{PM}_{10}$ explained by the independent variables, and the independent variables $\mathrm{RH}$ and $\mathrm{NO}_{2}$ are significant. This was done to know about the concentration of $\mathrm{PM}_{2.5} \& \mathrm{PM}_{10}$ and their correlation with other variables.

\section{Results and Discussion}

\subsection{Correlation between $P M_{2.5}, P M_{10}$, and other variables for Visakhapatnam.}

Table 1(a) indicates the significance levels between $\mathrm{PM}_{2.5}$ and $\mathrm{SO}_{2}, \mathrm{NO}, \mathrm{NO}_{2}, \mathrm{CO}$, and $\mathrm{RH}$, while Table 1(b) indicates the significance levels between $\mathrm{PM}_{10}$ and other parameters. Suppose the significance level (P-value) is less than 0.05. In that case, it shows that the respective parameter has passed the significance test and can be used for building a calculation model. From Table 1(a), it is clear that there is a significant positive correlation existing between $\mathrm{PM}_{2.5}$ and $\mathrm{RH}, \mathrm{PM}_{2.5}$, and CO. From Table 1(b), it is clear that there is a significant positive correlation existing between $\mathrm{PM}_{10}$ and $\mathrm{RH}, \mathrm{PM}_{10}$, and $\mathrm{NO}_{2}$. These results indicate that both $\mathrm{PM}_{2.5}$ and $\mathrm{PM}_{10}$ depend on relative humidity $(\mathrm{RH})$ apart from them depending on $\mathrm{CO}$ and the second depending on $\mathrm{NO}_{2}$ for this coastal station (Visakhapatnam) during the study period. Kuldeep Goswamy et al. [35] reported that relative humidity affected the incidence of COVID19 in Andhra Pradesh, where the present location of study Visakhapatnam is situated. At the same time, they found the relationship between COVID-19 and mean Relative Humidity was not consistent due to variation in incident meteorological variables. Here it should be noted that the same study for the period 2016 -2019 [36] indicated a significant positive correlation between $\mathrm{PM}_{2.5}$ and air pollutants while a significant negative correlation exists between $\mathrm{PM}_{2.5}$ and Relative Humidity.

\subsection{Concentration of PM2.5 and PM10at Visakhapatnam before and after lockdown.}

Figures 1 and 2 show the monthly variation of $\mathrm{PM}_{2.5}$ and $\mathrm{PM}_{10}$ concentrations for three years 2018 -2020, between March and August. The idea of these plots is to check their variation before the COVID-19 outbreak and its change before and after lockdown. 


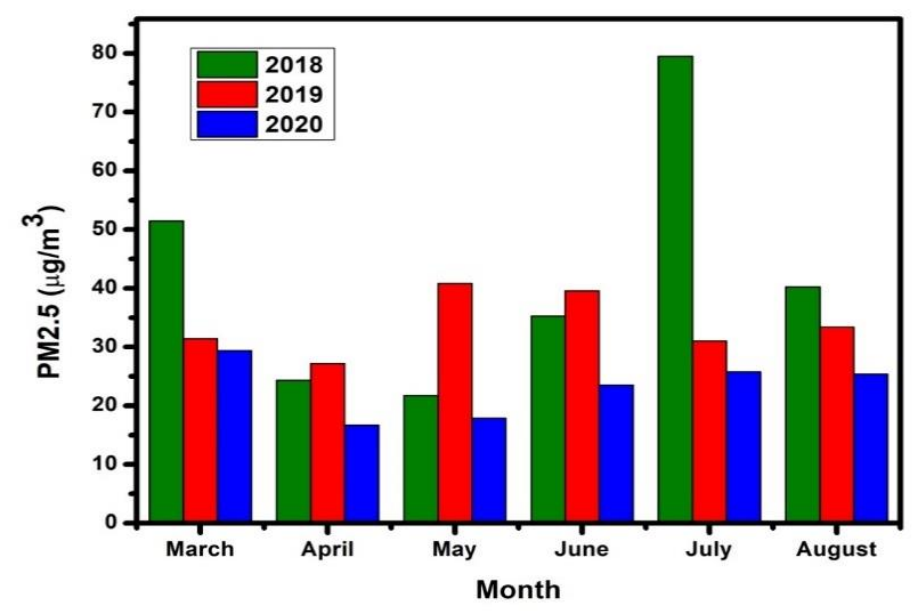

Figure 1. Plot showing the yearly variation of $\mathrm{PM}_{2.5}$ concentration.

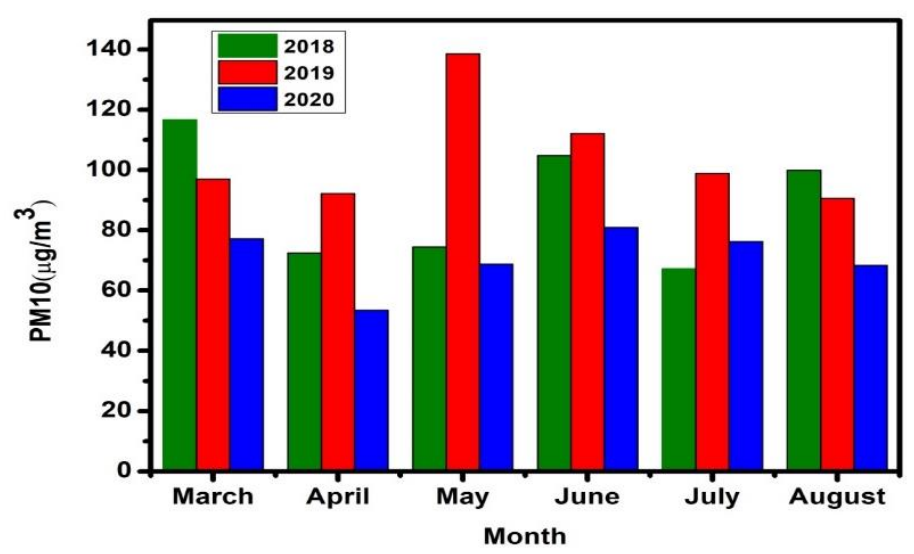

Figure 2. Plot showing the yearly variation of $\mathrm{PM}_{10}$ concentration.

The graphs are plotted with month on the x-axis and the corresponding monthly mean $\mathrm{PM}_{2.5}$ and $\mathrm{PM}_{10}$ concentration on the $\mathrm{y}$-axis from $1^{\text {st }}$ March 2018 to August $31^{\text {st }} 2020$. The plot indicates the impact of the lockdown implemented from March $25^{\text {th, }}$ 2020. The mean concentration is clearly seen decreasing during lockdown from March for all the three years of study.

\subsection{Variation of RH at Visakhapatnam before and after lockdown.}

Figure 3shows the monthly variation of RH for three years, 2018-2020 between March to August. This plot's idea is to check the variation of RH before the COVID-19 outbreak and its change before and after lockdown.

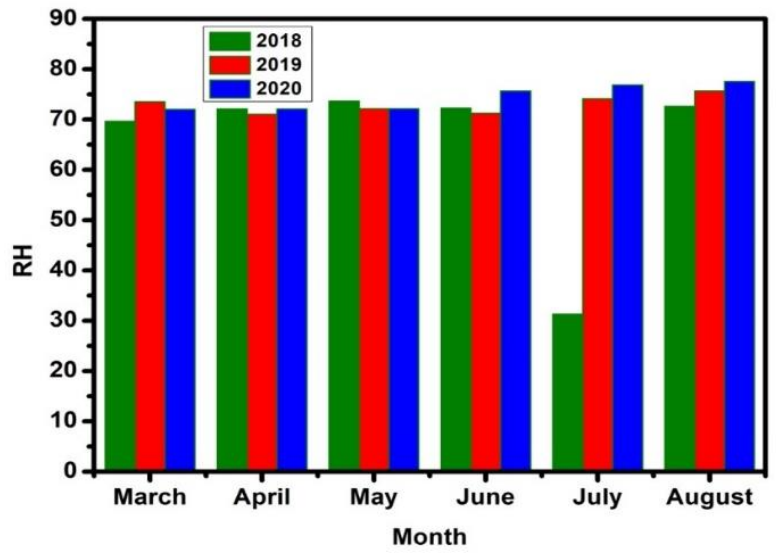

Figure 3 Plot showing the yearly variation of RH. 
The graph (Fig.3) was plotted with month on the x-axis and the corresponding monthly mean RH on the $y$-axis, between March $1^{\text {st }} 2018$, and August $31^{\text {st }} 2020$. The plot does not show any significant variation for all the three years of study irrespective of lockdown. This indicates that Relative Humidity is a parameter dependant on meteorological conditions but not dependant on vehicular traffic or other precursors that are intact during normal life conditions.

\subsection{Variation of $\mathrm{CO}, \mathrm{NO}, \mathrm{NO}_{2}$, and $\mathrm{SO}_{2}$ at Visakhapatnam before and after lockdown.}

Figure 4(a,b,c,d) shows the monthly variation of $\mathrm{CO}, \mathrm{NO}, \mathrm{NO}_{2}, \mathrm{SO}_{2}$ for three years 2018-2020 from March to August. These plots' idea is to check the variation of $\mathrm{CO}, \mathrm{NO}, \mathrm{NO}_{2}$, $\mathrm{SO}_{2}$ before the COVID-19 outbreak, and their changes before and after lockdown.

Fig.4(a,b,c,d) was plotted with month on the x-axis and the corresponding monthly mean values of $\mathrm{CO}, \mathrm{NO}, \mathrm{NO}_{2}$, and $\mathrm{NO}_{\mathrm{x}}$ on the $\mathrm{y}$-axis from March $1^{\text {st }} 2018$ to August $31^{\text {st }} 2020$. From these plots, it is clearly understood that $\mathrm{CO}$ has a steep decrease from $0.7 \mathrm{ppm}$ to $0.1 \mathrm{ppm}$ showing a huge decrease of about $85 \%$ (Fig.4a) after lockdown and thereby increased gradually based on the unlocking phase.
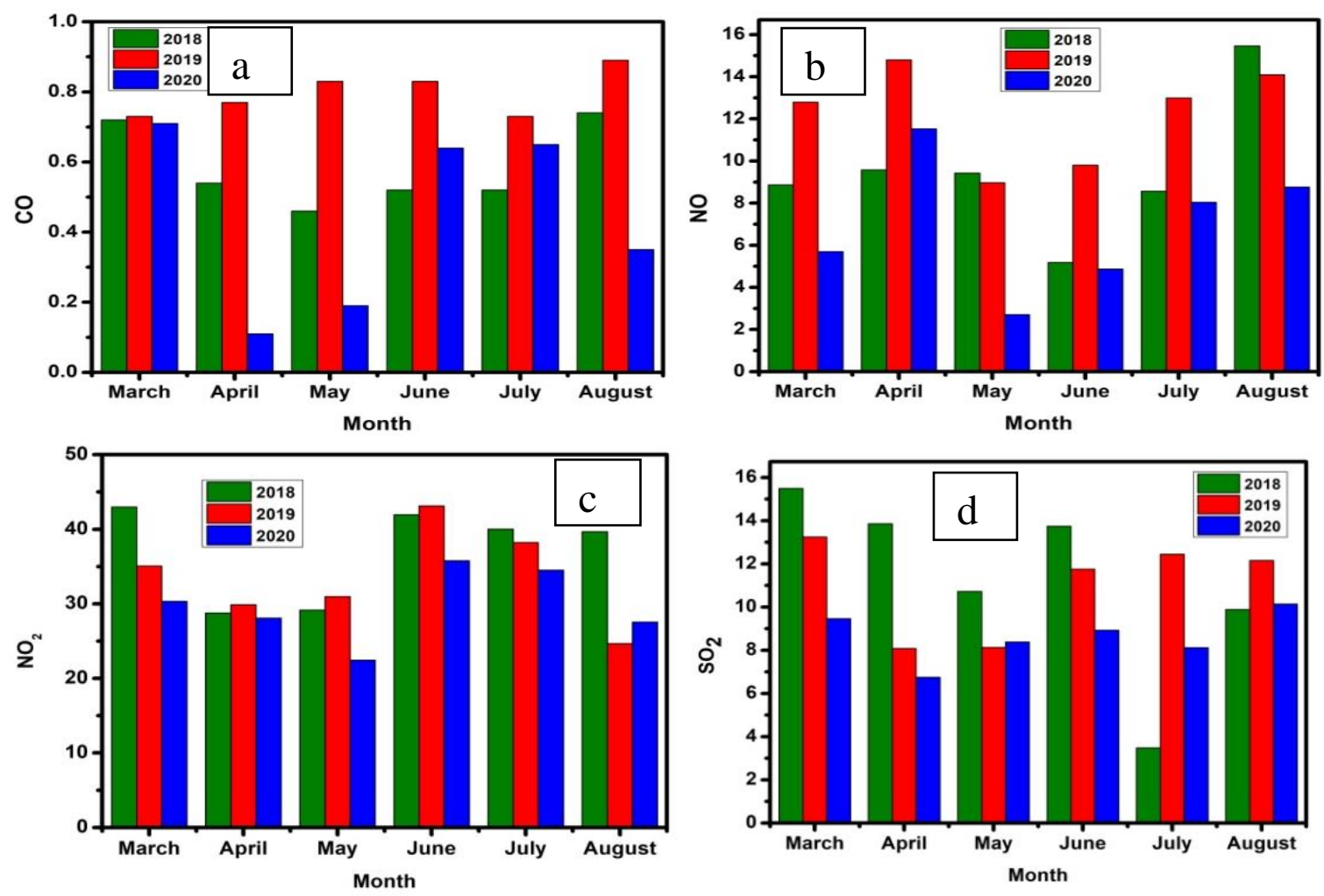

Figure 4.(a,b,c,d) Plots showing yearly variation of $\mathrm{CO}, \mathrm{NO}, \mathrm{NO}_{2}$,and $\mathrm{SO}_{2}$.

$\mathrm{CO}$ is a harmful gas and should not be inhaled in big amounts. This gas's main source is outdoor cars, trucks, and other vehicles that burn fossil fuels. Its impact on air quality is seen decreased during the lockdown as there is traffic reduction during this period. Similarly, NO shows a peculiar trend of initial increase after imposing lockdown and then followed the same trend as that of $\mathrm{CO}$ (Fig.4b). However, $\mathrm{NO}_{2}$ follows $\mathrm{CO}$ 's trend but without a huge increase or decrease in concentration (Fig.4c). Likewise, $\mathrm{SO}_{2}$ follows a similar trend as exhibited by $\mathrm{NO}_{2}$ (Fig.4d). The mean concentration is clearly seen decreasing during lockdown from March for all the three years of study. 


\section{Conclusions}

In this paper, we used the latest three years (2018-2020) data related to particulate matter and air pollutants from March to August of 2018-2020 for a coastal, urban, industrial station: Visakhapatnam. A multi-variant regression analysis between $\mathrm{PM}_{2.5}$ concentration and other variables was made. A similar correlation analysis between PM10 concentration and other variables was performed. The results show a significant positive correlation between $\mathrm{PM}_{2.5}$ and $\mathrm{RH}, \mathrm{PM}_{2.5}$ and $\mathrm{CO}, \mathrm{PM}_{10}$ and $\mathrm{RH}, \mathrm{PM}_{10}$, and $\mathrm{NO}_{2}$. These results indicate that both $\mathrm{PM}_{2.5}$ and $\mathrm{PM}_{10}$ depend on relative humidity $(\mathrm{RH})$ apart from $\mathrm{PM}_{2.5}$ dependence on $\mathrm{CO}$ and $\mathrm{PM}_{10}$ dependence on $\mathrm{NO}_{2}$ for this coastal station, Visakhapatnam study period. The main conclusions drawn are: Significant relevance exists between the concentrations of $\mathrm{PM}_{2.5}$ and $\mathrm{PM}_{10}$ with $\mathrm{NO}_{2}, \mathrm{CO}$, and $\mathrm{RH}$; The values of regression coefficients indicate a $70 \%$ correlation between $\mathrm{PM}_{2.5}$ and other variables while a $69 \%$ correlation between $\mathrm{PM}_{10}$ and other variables during lockdown for Visakhapatnam station; Relative Humidity $(\mathrm{RH})$ is the only parameter that does not show any significant change irrespective of lockdown. The value is almost the same for all the three years of study.

\section{Funding}

This research received no external funding.

\section{Acknowledgments}

The authors deeply acknowledge the Central Pollution Control Board for providing valuable data through its official website.

\section{Conflicts of Interest}

The authors declare no conflict of interest.

\section{References}

1. Madabhavi, I.; Sarkar, M.; Kadakol, N. COVID-19: a review. Monaldi Archives for Chest Disease 2020, 90, https://doi.org/10.4081/monaldi.2020.1298.

2. Chatterjee, P.; Nagi, N.; Agarwal, A.; Das, B.; Banerjee, S.; Sarkar, S.; Gupta, N.; Gangakhedkar, R.R. The 2019 novel coronavirus disease (COVID-19) pandemic: A review of the current evidence. Indian J. Med. Res. 2020, 151, 147, http://doi.org/10.4103/ijmr.IJMR_519_20.

3. Jiang, F.; Deng, L.; Zhang, L.; Cai, Y.; Cheung, C.W.; Xia, Z. Review of the clinical characteristics of coronavirus disease 2019 (COVID-19). J. Gen. Intern. Med. 2020, 1-5, http://doi.org/10.1007/s11606-02005762-w

4. World Health Organization, Ambient (Outdoor) Air Pollution,2018. Available online:https://www.who.int/news-room/fact-sheets/detail/ambient-(outdoor)-air-quality-and-health.

5. Padhi, A.; Kumar, S.; Gupta, E.; Saxena, S.K. Laboratory Diagnosis of Novel Coronavirus Disease 2019 (COVID-19) Infection. In Coronavirus Disease 2019 (COVID-19), Springer: 2020; 95-107, https://doi.org/10.1007/978-981-15-4814-7.

6. Cohen, A.J.; Brauer, M.; Burnett, R.; Anderson, H.R.; Frostad, J.; Estep, K.; Balakrishnan, K.; Brunekreef, B.; Dandona, L.; Dandona, R. Estimates and 25-year trends of the global burden of disease attributable to ambient air pollution: an analysis of data from the Global Burden of Diseases Study 2015. The Lancet 2017, 389, 1907-1918, https://doi.org/10.1016/S0140-6736(17)30505-6.

7. World Health Organization, 2018. Available online:https://www.who.int/data/gho/publications

8. Ng, C.F.S.; Hashizume, M.; Obase, Y.; Doi, M.; Tamura, K.; Tomari, S.; Kawano, T.; Fukushima, C.; Matsuse, H.; Chung, Y.; Kim, Y.; Kunimitsu, K.; Kohno, S.; Mukae, H. Associations of chemical composition and 
sources of PM2.5 with lung function of severe asthmatic adults in a low air pollution environment of urban Nagasaki, Japan. Environ. Pollut. 2019, 252, 599-606, https://doi.org/10.1016/j.envpol.2019.05.117.

9. World Most Polluted Cities, Meteosim, 2019. Available online:https://www.meteosim.com/en/world-mostpolluted-citie/.

10. Rodríguez-Urrego, D.; Rodríguez-Urrego, L. Air quality during the COVID-19: PM2.5 analysis in the 50 most polluted capital cities in the world. Environ. Pollut. 2020, 266, 115042, https://doi.org/10.1016/j.envpol.2020.115042.

11. Hanaoka, T.; Masui, T. Exploring effective short-lived climate pollutant mitigation scenarios by considering synergies and trade-offs of combinations of air pollutant measures and low carbon measures towards the level of the $2{ }^{\circ} \mathrm{C}$ target in Asia. Environ. Pollut. 2020, 261, 113650, https://doi.org/10.1016/j.envpol.2019.113650.

12. Dutheil, F.; Baker, J.S.; Navel, V. COVID-19 as a factor influencing air pollution? Environ. Pollut. 2020, 263 , 114466, https://doi.org/10.1016/j.envpol.2020.114466.

13. Muhammad, S.; Long, X.; Salman, M. COVID-19 pandemic and environmental pollution: A blessing in disguise? Sci. Total Environ. 2020, 728, 138820, https://doi.org/10.1016/j.scitotenv.2020.138820.

14. Mollalo, A.; Vahedi, B.; Rivera, K.M. GIS-based spatial modeling of COVID-19 incidence rate in the continental United States. Sci. Total Environ. 2020, $728, \quad 138884$, https://doi.org/10.1016/j.scitotenv.2020.138884.

15. Ogen, Y. Assessing nitrogen dioxide (NO2) levels as a contributing factor to coronavirus (COVID-19) fatality. Sci. Total Environ. 2020, 726, 138605, https://doi.org/10.1016/j.scitotenv.2020.138605.

16. Siciliano, B.; Dantas, G.; da Silva, C.M.; Arbilla, G. Increased ozone levels during the COVID-19 lockdown: Analysis for the city of Rio de Janeiro, Brazil. Sci. Total Environ. 2020, 737, 139765, https://doi.org/10.1016/j.scitotenv.2020.139765.

17. Adams, M.D. Air pollution in Ontario, Canada during the COVID-19 State of Emergency. Sci. Total Environ. 2020, 742, 140516, https://doi.org/10.1016/j.scitotenv.2020.140516.

18. To, T.; Zhang, K.; Maguire, B.; Terebessy, E.; Fong, I.; Parikh, S.; Zhu, J. Correlation of ambient temperature and COVID-19 incidence in Canada. Sci. Total Environ. 2021, 750, 141484, https://doi.org/10.1016/j.scitotenv.2020.141484.

19. Wang, Y.; Yuan, Y.; Wang, Q.; Liu, C.; Zhi, Q.; Cao, J. Changes in air quality related to the control of coronavirus in China: Implications for traffic and industrial emissions. Sci. Total Environ. 2020, 731, 139133, https://doi.org/10.1016/j.scitotenv.2020.139133.

20.Zoran, M.A.; Savastru, R.S.; Savastru, D.M.; Tautan, M.N. Assessing the relationship between surface levels of PM2.5 and PM10 particulate matter impact on COVID-19 in Milan, Italy. Sci. Total Environ. 2020, 738, 139825, https://doi.org/10.1016/j.scitotenv.2020.139825.

21. Wang, P.; Chen, K.; Zhu, S.; Wang, P.; Zhang, H. Severe air pollution events not avoided by reduced anthropogenic activities during COVID-19 outbreak. Resources, Conservation and Recycling 2020, 158, 104814, https://doi.org/10.1016/j.resconrec.2020.104814.

22. Xiang, J.; Austin, E.; Gould, T.; Larson, T.; Shirai, J.; Liu, Y.; Marshall, J.; Seto, E. Impacts of the COVID19 responses on traffic-related air pollution in a Northwestern US city. Sci. Total Environ. 2020, 747, 141325, https://doi.org/10.1016/j.scitotenv.2020.141325.

23. Chauhan, A.; Singh, R.P. Decline in PM2.5 concentrations over major cities around the world associated with COVID-19. Environ. Res. 2020, 187, 109634, https://doi.org/10.1016/j.envres.2020.109634.

24.Zheng, H.; Kong, S.; Chen, N.; Yan, Y.; Liu, D.; Zhu, B.; Xu, K.; Cao, W.; Ding, Q.; Lan, B. Significant changes in the chemical compositions and sources of PM2. 5 in Wuhan since the city lockdown as COVID19. Sci. Total Environ. 2020, 140000, https://doi.org/10.1016/j.scitotenv.2020.140000.

25. Baldasano, J.M. COVID-19 lockdown effects on air quality by NO2 in the cities of Barcelona and Madrid (Spain). Sci. Total Environ. 2020, 741, 140353, https://doi.org/10.1016/j.scitotenv.2020.140353.

26. Lou, C.; Liu, H.; Li, Y.; Peng, Y.; Wang, J.; Dai, L. Relationships of relative humidity with PM 2.5 and PM 10 in the Yangtze River Delta, China. Environ. Monit. Assess. 2017, 189, 582, https://doi.org/10.1007/s10661017-6281-z.

27. Sharma, S.; Zhang, M.; Anshika; Gao, J.; Zhang, H.; Kota, S.H. Effect of restricted emissions during COVID19 on air quality in India. Sci. Total Environ. 2020, 728, 138878, https://doi.org/10.1016/j.scitotenv.2020.138878.

28. Kumar, P.; Hama, S.; Omidvarborna, H.; Sharma, A.; Sahani, J.; Abhijith, K.V.; Debele, S.E.; Zavala-Reyes, J.C.; Barwise, Y.; Tiwari, A. Temporary reduction in fine particulate matter due to 'anthropogenic emissions 
switch-off' during COVID-19 lockdown in Indian cities. Sustainable Cities and Society 2020, 62, 102382, https://doi.org/10.1016/j.scs.2020.102382.

29. Chowdhuri, I.; Pal, S.C.; Saha, A.; Chakrabortty, R.; Ghosh, M.; Roy, P. Significant decrease of lightning activities during COVID-19 lockdown period over Kolkata megacity in India. Sci. Total Environ. 2020, 747, 141321, https://doi.org/10.1016/j.scitotenv.2020.141321.

30. Mahato, S.; Pal, S.; Ghosh, K.G. Effect of lockdown amid COVID-19 pandemic on air quality of the megacity Delhi, India. Sci. Total Environ. 2020, 730, 139086, https://doi.org/10.1016/j.scitotenv.2020.139086.

31. Central Pollution Control Board. Available online:http://cpcb.nic.in/

32. Darapu, S.S.K. Air Pollution In Visakhapatnam -An Overview. International Journal of Civil Engineering (IJCE) 2013, 2, 11-14.

33. Police, S.; Sahu, S.K.; Pandit, G.G. Chemical characterization of atmospheric particulate matter and their source apportionment at an emerging industrial coastal city, Visakhapatnam, India. Atmospheric Pollution Research 2016, 7, 725-733, https://doi.org/10.1016/j.apr.2016.03.007.

34. Central Control Room for Air Quality Management. Available online: https://app.cpcbccr.com/ccr/\#/caaqmdashboard-all/caaqm-landing/data.

35. Goswami, K.; Bharali, S.; Hazarika, J. Projections for COVID-19 pandemic in India and effect of temperature and humidity. Diabetes \& Metabolic Syndrome: Clinical Research \& Reviews 2020, 14, 801-805, https://doi.org/10.1016/j.dsx.2020.05.045.

36. Prasad, N.V.K.; Sarma, M.; Sasikala, P.; Madhavi, N. Regression Model to Analyse Air Pollutants Over a Coastal Industrial Station Visakhapatnam (India). International Journal of Data Science 2020, 1, 107-113, http://doi.org/10.18517/ijods.1.2.107-113.2020. 